\title{
REMEDIES FOR NONCOMPLIANCE WITH SECTION 553 OF THE ADMINISTRATIVE PROCEDURE ACT: A CRITICAL EVALUATION OF UNITED STATES STEEL AND WESTERN OIL \& GAS
}

Under section 553 of the Administrative Procedure Act (APA), ${ }^{1}$ federal administrative agencies must im most imstances ${ }^{2}$ follow definite procedures when promulgatimg rules. ${ }^{3}$ Many rules are challenged on the ground that the promulgating agency did not comply with the requirements of section 553. The overwhelming majority of the courts that sustam such challenges immediately invalidate the challenged rule.

1. 5 U.S.C. $\& 553$ (1976).

2. Under certain circumstances, agencies need not follow any set procedures when promulgating rules that have the force and effect of law. See note 3 and text accompanying notes 15-19 infra.

3. The APA prescribes two geueral sets of procedural requirements. The first set contains the procedures required for what is commonly called "informal" rulemaking. These procedures, set forth at 5 U.S.C. $\$ 553$ (1976), are the topic of this note. The second set contains the procedures involved in "formal" rulemaking. Formal rulemaking is essentially informal rulemaking plus hearings and elaborate record-keeping. See id. $\$ \S 556-557$. For a discussion of formal and informal rulemaking procedure, see $1 \mathrm{~K}$. DAVIS, ADMINISTRATIVE LAw TREATISE § 6:1-6:3 (2d ed. 1978); Auerbach, Informal Rule Making: A Proposed Relationship Between Administrative Procedures and Judicial Review, 72 Nw. U.L. Rev. 15 (1977); Fuchs, Development and Diversification in Administrative Rule Making, 72 Nw. U.L. REv. 83 (1977).

Geuerally, formal procedures are required only when a statute calls for hearings "on the record," either in those words or in similar language. United States v. Florida E.C. Ry., 410 U.S. 224, 234-38(1973); United States v. Allegheny-Ludlum Steel Corp., 406 U.S. 742, $756-57$ (1972); Hercules, Inc. v. EPA, 598 F.2d 91, 119 n.53 (D.C. Cir. 1978). See generally Robinson, The Making of Administrative Policy: Another Look at Rulemaking and Adjudication and Administrative Procedure Reform, 118 U. PA. L. Rev. 485 (1970). Most other rulemaking is informal.

Certain agency actions, such as statements of policy, and some rulemaking, rcquire no procedures. For discussion of situations in which no procedures are required see National Retired Teachers Ass'n v. United States Postal Serv., 593 F.2d 1360, 1364-65 (D.C. Cir. 1979); Reynolds Metals Co. v. Rumsfeld, 564 F.2d 663, 669-70 (4th Cir. 1977), cert. denied, 435 U.S. 995 (1978); Pickus v. United States Bd. of Parole, 507 F.2d 1107, 1111-14 (D.C. Cir. 1974); Dow Chem., USA v. Consumer Prod. Safety Comm'n, 464 F. Supp. 904, 908-10 (W.D. La. 1979); Asimow, Public Participation in the Adoption of Interpretative Rules and Policy Statements, 75 Mich. L. REV. 521 (1977); Hamilton, Procedures for the Adoption of Rules of General Applicability: The Need for Procedural Innovation in Administrative Rulemaking, 60 CALIF. L. REv. 1276 (1972). See also text accompanying notes 15-19 infra. 
In the recent cases of United States Steel Corp. v. EPA $A^{4}$ and Western Oil $\&$ Gas Association v. EPA, ${ }^{5}$ however, the Courts of Appeals for the Eighth and Ninth Circuits sustained procedural challenges but left the improperly promulgated rules temporarily in effect. ${ }^{6}$

In response to this recent departure from precedent, this note examines the question of what remedy is appropriate following a successful procedural challenge to a rule promulgated pursuant to section 553. Part one outlines the procedures prescribed by section 553 and surveys the cases in which courts have fashioned relnedies following a finding of agency noncoinpliance with this statute. Part two examines the competing considerations in cases involving successful procedural challenges to informal rulemaking, and suggests that the formulation of a reinedy requires an equitable, balancing approach. This approach allows a court to be responsive to exigent circumstances in a given case, avoiding an often unjust and unreasonable result. Part three is a critical evaluation of United States Steel and Western Oil \& Gas in hight of the balancing approach discussed in part two.

\section{Conflicting Judicial Remedies for Section 553 Violations}

Congress passed the APA in an effort "to improve the administration of justice by prescribing fair administrative procedure." 7 Section 553 of the Act prescribes the minimuin ${ }^{8}$ procedures that agencies are in most instances obliged to follow when promulgating rules.9 The rulemaking process under section 553 commences when the agency

4. 649 F.2d 572 (8th Cir. 1981).

5. 633 F.2d 803 (9th Cir. 1980).

6. See text accompanying notes 104-08 infra.

7. Senate Comm. on the Judiciary, Administrative Procedure Act: Report of the CommitTeE on the Judiciary, S. ReP. No. 752, 79th Cong., 1st Sess. 7 (1945), reprinted in LeGislative History of the Administrative Procedure Act, S. Doc. No. 248, 79th Cong., 2d Sess. 1, 187 (1946) [hereinafter cited as Leaislative HistoRY].

8. Compare 5 U.S.C. $\$ 553$ (1976) with id. $\S \S 556-557$. See note 3 supra.

9. Section 553 reads, in pertinent part:

(b) General notice of proposed rule inaking shall be published in the Federal Register, unless persons subject thereto are named and either personally served or otherwise have actual notice thereof in accordance with law. The notice shall include-

(1) a statement of the time, place, and nature of public rule making proceedings;

(2) reference to the legal authority under which the rule is proposed; and

(3) either the terms or substance of the proposed rule or a description of the subjects and issues involved. Except when notice or hearing is required by statute, this subsection does not apply-

(B) when the agency for good cause finds (and imcorporates the finding and a brief statement of reasons therefor in the rules issued) that notice and public procedure thereon are impracticable, unnecessary, or contrary to the public interest.

(c) After notice required by this section, the agency shall give interested persons an opportunity to participate in the rule inaking through submission of written data, views, or arguments with or without opportunity for oral presentation. After cousideration of the 
publishes notice of proposed rulemaking in the Federal Register. ${ }^{10}$ The agency then receives and considers comment from interested parties. ${ }^{11}$ Following the comment period, the agency publishes a final rule ${ }^{12}$ along with a statement of its basis and purpose. ${ }^{13}$ The final rule can be effective no sooner than thirty days from the date of its publication in final form. 14

Section 553 allows agencies to forego the above procedures in certain situations. If "a military or foreign affairs function of the United States . . . [or] a matter relatimg to agency management or personnel or to public property, loans, grants, benefits, or contracts" is the subject of rulemaking, the promulgating agency may disregard the procedures of

relevant matter presented, the agency shall incorporate in the rules adopted a concise general statement of their basis and purpose ....

(d) The required publication or service of a substantive rule shall be made not less than 30 days before its effective date, except-

(1) a substantive rule which grants or recognizes an exemption or relieves a restriction;

(2) interpretative rules and statements of policy; or the rule.

(3) as otherwise provided by the agency for good cause found and published with

10. See 5 U.S.C. $\$ 553(\mathrm{~b})$ (1976). The type of notice that an agency must give has been at issue in a number of cases. In general, the notice must afford "interested parties a reasonable opportunity to participate in the rulemaking process." Forester v. Consumer Prod. Safety Comm'n, 559 F.2d 774, 787 (D.C. Cir. 1977). The notice must specifically announce that the agency inteuds to promulgate a rule. National Tour Brokers Ass'n v. United States, 591 F.2d 896 (D.C. Cir. 1978). Also, the notice must reach all similarly situated parties, not just selected individuals. Wagner Elec. Corp. v. Volpe, 466 F.2d 1013, 1019-20 (3d Cir. 1972). See also American Iron \& Steel Inst. v. EPA 568 F.2d 284, 291-92 (3d Cir. 1977); United States v. Daniels, 418 F.Supp. 1074 (D.S.D. 1976).

11. 5 U.S.C. $\$ 553(\mathrm{c})(1976)$.

12. Final rules may differ substantially from proposed rules. See BASF Wyandotte Corp. v. Costle, 598 F.2d 637 (1st Cir. 1979), cert. denied, 444 U.S. 1096 (1980); South Terminal Corp. v. EPA, 504 F.2d 646 (1st Cir. 1974). One commentator lias proposed that, in sucl a case, an additional notice and comment period be instituted prior to the effective date of the rule. Comment, The Need for an Additional Notice and Comment Period When Final Rules Differ Substantially From Interim Rules, 1981 DUKe L.J. 377.

13. 5 U.S.C. $\& 553$ (c) (1976). The courts have generally held that the statement of basis and purpose need not coutain specific details and findings of fact to support the agency's decisions. See, e.g., National Nutritional Foods Ass'n v. Weinberger, 512 F.2d 688, 701 (2d Cir. 1975); American Medical Ass'n v. Mathews, 429 F. Supp. 1179, 1204-05 (N.D. Ill. I977). The statement must, however, "respond in a reasoned manner to the comments received, . . . explain how thc agency resolved any significant problems raised by the comments, and . . . show how that resolution led the agency to the ultimate rule." Rodway v. USDA, 514 F.2d 809, 817 (D.C. Cir. 1975). Similarly, the statement "inust be sufficiently detailed and informative to allow a scarching judicial scrutiny of how and why the regulations were actually adopted." Amoco Oil Co.v. EPA, 501 F.2d 722, 739 (D.C. Cir. 1974). But cf. Nathanson, Probing the Mind of the Administrator: Hearing Variations and Standards of Judicial Review Under the Administrative Procedure Act and Other Federal Statutes, 75 Colunt. L. Rev. 721, 754-55 (1975). ("There is not the slightest indication that the purpose of the notice-and-comment proceeding was to develop a record by which a reviewing court could test the validity of the rule which the Administrator finally adopted.")

14. 5 U.S.C. $\S 553$ (d) (1976). 
the section. 15 The agency may also disregard the procedures when "interpretative rules, general statements of policy, or rules of agency organization, procedure, or practice" are involved.16

Section 553 also contaims two "good cause" exceptions to its procedural requirements. ${ }^{17}$ First, if "the agency for good cause finds . . . that notice and public procedure thereon are impracticable, unnecessary, or contrary to the public imterest,"18 it may forego notice and comment. The second "good cause" exception allows agencies to make rules effective in less than thirty days upon "good cause found and published with the rule."19

Simce the enactment of the APA, numerous rules have been challenged on the ground that the proinulgating agency did not comply with the procedural requirements of section 553.20 Most courts $^{21}$ sus-

15. Id. § 553(a). See National Wildlife Fed'n v. Snow, 561 F.2d 227 (D.C. Cir. 1976); Housing Auth. of Omaha v. United States Hous. Auth., 468 F.2d 1 (8th Cir. 1972), cert. denied, 410 U.S. 927 (1973). See generally, Bonfield, Public Participation in Federal Rulemaking Relating to Public Property, Loans, Grants, Benefits, or Contracts, 118 U. PA. L. REv. 540 (1970).

16. 5 U.S.C. $\$ 553(\mathrm{~b})(3)(\mathrm{A})(1976)$. Agency attempts, both successful and unsuccessful, to rely on the section 553(b)(3)(A) exception are numerous. See American Bus Ass'n v. United States, 627 F.2d 525 (D.C. Cir. 1980) and cases cited in note 3 supra.

17. 5 U.S.C. $\$ \S 553(\mathrm{~b})(\mathrm{B}), 553$ (d)(3) (1976). The legislative history of the APA cautions agencies not to use the good cause exceptions as escape clauses. See LeglSLATIVE HiSTORY, supra note 7 , at $19,200,258$. Accordingly, courts normally have construed these exceptions narrowly. See Mobil Oil Corp. v. DOE, 610 F.2d 796 (Teinp. Emer. Ct. App. 1979), cert. denied, 100 S.Ct. 2156 (1980); United States v. Gavrilovic, 551 F.2d 1099 (8th Cir. 1977); Detroit Edison Co. v. EPA, 496 F.2d 244 (5th Cir. 1974). But see Texaco, Inc. v. Federal Energy Admin., 531 F.2d 1071 (Temp. Emer. Ct. App.), cert. denied, 426 U.S. 941 (1976); Pent-R-Books, Inc. v. United States Postal Serv., 328 F. Supp. 297, 312 (E.D.N.Y. 1971). Agencies successfully invoked the good cause exceptions in the following cases: Washington State Farm Bureau v. Marshall, 625 F.2d 296 (9th Cir. 1980); DeRieux v. Five Smiths, Inc., 499 F.2d 1321 (Teinp. Emer. Ct. App.), cert. denied, 419 U.S. 896 (1974). For general discussion of the good cause exceptions, see Comment, Agency Discretion to Accept Comment in Informal Rulemaking: What Constitutes "Good Cause" Under the Administrative Procedure Act? 1980 B.Y.U. L. REv. 93; Note, The "Good Cause" Exceptions: Danger to Notice and Comment Requirements Under the Administrative Procedure Act, 68 GEo. L.J. 765 (1980); Comment, The Good Cause Exceptions from Administrative Rulemaking Requirements: Divergent Views in the Clean Air Cases, 49 U. CrN. L. REv. 624 (1980).

18. 5 U.S.C. $\S 553(\mathrm{~b})(\mathrm{B})$ (1976).

19. Id. $\S 553(\mathrm{~d})(3)$.

20. See, e.g., Rowell v. Andrus, 631 F.2d 699 (10th Cir. 1980) (regulation raising annual payment for oil and gas leases froun \$.50 to \$1.00); Kollett v. Harris, 619 F.2d 134 (1st Cir. 1980) (regulation attributing to a disabled child certain income of parents or step-parents); United States v. Gavrilovic, 551 F.2d 1099 (8th Cir. 1977) (regulation placing mecloqualone on list of controlled substances); American Frozen Food Inst. v. Train, 539 F.2d 107 (D.C. Cir. 1976) (regulations creating effluent limitations for potato-processing industry); Pickus v. United States Bd. of Parole, 507 F.2d 1107 (D.C. Cir. 1974) (regulations concerning parole eligibility); California Citizens Band Ass'n v. United States, 375 F.2d 43 (9th Cir. 1967) (FCC regulations pertaiming to Citizens Radio Service).

21. The power of courts to review agency action

may be found in (1) a statute which specifically states that orders or other actions of the named agency nuay be reviewed ... or contains a general provision for judicial review 
taining such procedural challenges ${ }^{22}$ immediately invalidate the rule and remand the case to the agency with imstructions to follow proper section 553 procedures. ${ }^{23}$ The Court of Appeals for the District of

of administrative action . . . ; or (2) a grant of general jurisdiction-either by statute, such as a code of procedure, or under the common law or by constitution.

W. Gellhorn, C. Byse \& P. Strauss, Administrative Law 917 (7th ed. 1979). This power of judicial review has been the focus of a plethora of case law and commentary. With respect to judicial review of agency procedure, the leading case is Vermont Yankee Nuclear Power Corp. v. Natural Resources Defense Council, 435 U.S. 519 (1978). Vermont Yankee held generally that a court must not impose on an agency more restrictive procedures than those required under the APA. Id. at 524. For comment on and criticism of Vermont Yankee, see $1 \mathrm{~K}$. Davis, supra note 2, $\S 6: 37$ (20 ed. Supp. 1980); Davis, Administrative Law and the Vermont Yankee Opinion, 1980 UTAH L. REV. 3; Stewart, Vermont Yankee and the Evolution of Administrative Procedure, 91 HARV. L. REV. 1805 (1978).

22. An extensive analysis of when a procedural challenge should be sustained is beyond the scope of this note. Briefiy, if an agency unjustifiably fails to meet the procedural requirenents discussed in notes 8-14 supra and accompanying text, it violates section 553. Several courts have held, however, that a minor deviation from strict section 553 procedures does not ainount to a violation. See National Helium Corp. v. Federal Energy Admin., 569 F.2d 1137, 1144 (Temp. Emer. Ct. App. 1977); Alabaina Ass'n of Ins. Agents v. Board of Governors of the Fed. Reserve Sys., 553 F.2d 224, 236-37 (5th Cir. 1976), vacated in part, 558 F.2d 729 (5th Cir. 1977), cert. denied, 435 U.S. 904 (1978).

23. In most instances, the court declares the rule null and void, apparently following 5 U.S.C. $\S 706$ (1976): "The reviewing court slall . . . (2) hold unlawful and set aside agency action, findings, and conclusion found to be . . . (D) without observance of procedure required by law." In some cases, the petitioning party requests equitable relief, and the court enjoins the proinulgating agency from enforcing the challenged rule. See, e.g., Dow Chemical, USA v. Consumer Prod. Safety Comm'n, 464 F. Supp. 904 (W.D. La. 1979); Community Nutrition Inst. v. Butz, 420 F. Supp. 751 (D.D.C. 1976). Most courts use this remedy as a matter of course, seemingly without considering whether alternatives are available. See, e.g., PPG Indus., Inc. v. Costle, 659 F.2d 1239 (D.C. Cir. 1981); Mobil Oil Corp. v. DOE, 610 F.2d 796, 806 (Temp. Emer. Ct. App. 1979), cert. denied, 446 U.S. 937 (1980); City of New York v. Diamond, 379 F. Supp. 503 (S.D.N.Y. 1974).

In a few isolated imstances prior to United States Steel and Western Oil \& Gas, courts left challenged rules temporarily in effect. For example, in Rodway v. USDA, 514 F.2d 809 (D.C. Cir. 1975), neinbers of low-income households challenged a food-stamp allocation program that had been instituted without any of the procedures required by section 553 . The court held that the prograin was invalidly promulgated and remanded the case, but left the program in effect until a properly promulgated substitute was in place. $I d$. at 817,824 . The Rodway court was not, however, asked to invalidate the program. Although the plaintiffs originally asked the court to enjoin enforcement of the allocation prograin because it increased the cost of food stamps, they withdrew their request after the Department of Agriculture rolled back the price increase. $I d$. at 812 . See also Natural Resources Defense Council, Inc. v. SEC, 389 F. Supp. 689, 699 (D.D.C. 1974).

One of the rare cases that clearly contradiets the majority rule prior to United States Steel and Western Oil \& Gas is National Nutritional Foods Ass'n v. Weinberger, 512 F.2d 688 (2d Cir.), cert. denied, 423 U.S. 827 (1975). National Nutritional Foods involved a challenge to FDA regulations that classified certain preparations of vitamins A and D as "prescription drugs" rather than as food. The court held that the agency had not provided an adequate statement of basis and purpose as required by section 553 (c). Instead of invalidating the challenged regulations as the plaintiff requested, the court left the regulations in effect and remanded the case for further proceedings. The Court of Appeals for the District of Columbia Circuit criticized the National Nutritional Foods case at length in Tabor v. Joimt Bd. for Enrollment of Actuaries, 566 F.2d 705 (D.C. Cir. 1977). The Tabor court convincingly demonstrated that the National Nutritional Foods court misread and misapplied the cases on which it based its decision. Id. at 711-12. It is interest- 
Columbia Circuit followed this practice in Tabor v. Joint Board for Enrollment of Actuaries. ${ }^{24}$

In Tabor, experienced actuaries challenged regulations establisl1ing standards and qualifications for persons performing actuarial services for pension plans to which the Employee Retirement Income Security Act of $1974^{25}$ (ERISA) applies. ${ }^{26}$ The actuaries argued, inter alia, that the Joint Board had violated section 553 by failing to publish a stateinent of basis and purpose with the rules. ${ }^{27}$ The district court granted the Board's inotion for summary judgment. ${ }^{28}$ The Court of Appeals for the First Circuit reversed, vacating the rules and remanding the case to the Board "to enable it to adopt new rules accompamed by a contemporaneous statement of basis and purpose." 29

In United States Steel Corp. v. EPA ${ }^{30}$ and Western Oil \& Gas Association v. EPA, ${ }^{31}$ the Courts of Appeals for the Eiglth and Nintl Circuits proposed a new remedy for agency noncomphance witl section 553. Both cases arose out of the 1977 ainendments to the Clean Air Act (CAA). ${ }^{32}$ Under the amended CAA, each state submitted to the Environmental Protection Agency (EPA) a list categorizing the areas of the

ing to note that, the Court of Appeals for the Second Circuit, which left the regulations in effect in National Nutritional Foods, chose in other cases to invalidate challenged rules immediately. See United States v. Nova Scotia Food Prod. Corp., 568 F.2d 240 (2d Cir. 1977); Lewis-Mota v. Secretary of Labor, 469 F.2d 478 (2d Cir. 1972).

24. 566 F.2d 705 (D.C. Cir. 1977).

25. Pub. L. No. $96-364,94$ Stat. 1210 (codified in scattered sections of 29 U.S.C.).

26. 566 F.2d at 707. Section 3041 of ERISA, 29 U.S.C. $\$ 1241$ (1976) directs the Secretary of the Treasury and the Secretary of Labor to establish the Joint Board for the Enrollment of Actuaries. The Joint Board is to "establish reasonable standards and quahifications for persons performing actuarial services with respect to plans in which this Act applies." Id. § 1242. Pursuant to this directive, the Joint Board proposed a set of regulations that was adopted as final on January 14, 1976. 566 F.2d at 707. These regulations were the subject of the Tabor case.

27. Id. at 709-10.

28. Id. at 706 .

29. Id. at 712 .

30. 649 F.2d 572 (8th Cir. 1981).

31. 633 F.2d 803 (9th Cir. 1980).

32. 42 U.S.C. $\$ \$ 7401-7642$ (Supp. III 1979). For discussion of the 1977 Amendments see Currie, Relaxation of Implementation Plans Under the 1977 Clean Air Act Amendments, 78 MicH. L. REv. 155 (1979).

Under the Clean Air Act Amendments of 1970, 42 U.S.C. $\$ \S 1857-1858$ (1976) (aniended 1977), the Administrator of the EPA established air-quality standards for designated air pollutants. The standards have been in force since Noventber 25, 1971 and are codified at 40 C.F.R. $\S 850.1-50.11$ (1981). The states were required to develop plans to incet the standards by 1975 . In 1977, because the deadline imposed by the 1970 legislation was not net, Congress amended the CAA to restructure the scheme for attaining the standards set up in 1970. Under the 1977 annendnents, the states nust neet the air-quality standards for nrost pollutants by Decenber 31, 1982, 42 U.S.C. 7502(a) (Supp. III 1979), and they must meet the standards for certain other pollutants (photochemical oxidants or carbon nonoxide, or both) by 1987 if earlier attainment proves impossible. Id. \&7502(b). 
state according to the Act's air-quality standards. ${ }^{33}$ An area that met the standards was listed as an "attainment" area; an area that failed to meet the standards was designated a "nonattainment" area. ${ }^{34}$ The EPA Administrator proinulgated a final version of the states' lists of designations" ${ }^{35}$ after making "sucl modifications as he deein[ed] necessary." 36 The states were then to base new plans to attain proper air quality on the Administrator's final lists. ${ }^{37}$

The Amendinents called for promulgation of the final lists by February 3, 1978.38 The EPA did not, however, publish the final lists in the Federal Register until March 3, 1978. ${ }^{39}$ This publication, the first pubhic notice of the lists, included instructions that they were to be effective immediately..$^{40}$

Following the March 3, 1978 publication, a number of parties petitioned for review of the Administrator's actions in promulgating the final lists. ${ }^{41}$ The parties argued that the EPA had not coinplied witl section 553 because it had publislied the final lists effective immediately, without prior notice or a coinment period. ${ }^{42}$ They sought the

33. 42 U.S.C. \$ 7407(d) (Supp. III 1979).

34. United States Steel Corp. v. EPA, 649 F.2d at 574. An area that had a nonattainment designation on the final list became subject to the EPA's "offset" pohicy. The offset policy, first mentioned in an interpretive ruling, 41 Fed. Reg. 55,524 (1976), was adopted in the CAA Amendments of 1977, 42 U.S.C. $\$ 7503$ (Supp. III 1979). As the United States Steel court noted:

This policy places strict limitations on the construction of new facilities, or the nodification of existing facilities, that will increase the overall level of pollution emissions in a nonattainment area. Construction or modification in a nonattainment area will be permitted only if the increase in emissions attributable to the new source would be offset by a greater decrease im emissions attributable to existing sources. Construction of a new source of emissions may be disapproved if it will contribute to a violation of air quality standards in a nearby area.

649 F.2d at 576 n.8.

35. See 43 Fed. Reg. 8962 (1978).

36. The Administrator's derived authority to modify the designations from 42 U.S.C. $\S 7407$ (d)(2) (Supp. III 1979).

37. Id. $\$ 7407$.

38. $I d . \S 7407$ (d).

39. 43 Fed. Reg. 8962 (1978).

40. Id. The publication also stated that the agency would accept post-pronulgation coinment on the designations and would publish revised designations as appropiate.

41. See, e.g., United States Steel Corp. v. EPA, 649 F.2d 572 (8th Cir. 1981); Westeru Oil \& Gas Ass'n v. EPA, 633 F.2d 803 (9th Cir. 1980); New Jersey v. EPA, 626 F.2d 1038 (D.C. Cir. 1980); Republic Steel Corp. v. Costle, 621 F.2d 797 (6th Cir. 1980); Umited States Steel Corp. v. EPA, 605 F.2d 283 (7th Cir. 1979), cert. denied, 444 U.S. 1035 (1980); Sharon Steel Corp. v. EPA, 597 F.2d 377 (3rd Cir. 1979); Umited States Steel Corp. v. EPA, 595 F.2d 207 (5th Cir.), modified on rehearing, 598 F.2d 915 (1979).

42. See, e.g., United States Steel Corp. v. EPA, 649 F.2d at 573-76; Western Oil \& Gas Ass'n v. EPA, 633 F.2d at 806, 810-12; New Jersey v. EPA, 626 F.2d at 1041-42; Republic Steel Corp. v. Costle, 621 F.2d at 799, 802-03; United States Steel Corp. v. EPA, 605 F.2d at 285-86; Slaron Steel Corp. v. EPA, 597 F.2d at 379; United States Steel Corp. v. EPA, 595 F.2d at 210, 212-13. 
invalidation of the nonattainment designations that affected them..$^{43}$ The EPA admitted that it did not follow the procedures in section $553,{ }^{44}$ but argued that the February 3, 1978 deadline provided sufficient "good cause" under section 553(b)(B) to allow it to forego normal rulemaking procedures. 45

Seven federal courts of appeals considered the petitions. The EPA's "good cause" argument succeeded in the Courts of Appeals for the Sixth ${ }^{46}$ and Seventh ${ }^{47}$ Circuits, but failed elsewhere. ${ }^{48}$ The Courts of Appeals for the Third, ${ }^{49}$ Fifth $^{50}$ and District of Columbia ${ }^{51}$ Circuits rejected the EPA's good cause argument, invalidated the challenged designations, and remanded the cases to the agency for proceedings in comphance with section 553.52 The Court of Appeals for the Eighth Circuit in United States Steel and the Court of Appeals for the Ninth Circuit in Western Oil \& Gas also rejected the EPA's argument, ${ }^{53}$ and

43. See, e.g., United States Steel Corp. v. EPA, 649 F.2d at 577; Western Oil \& Gas Ass'n v. EPA, 633 F.2d at 812; New Jersey v. EPA, 626 F.2d at 1042; Republic Steel Corp. v. Costle, 621 F.2d at 802; United States Steel Corp. v. EPA, 605 F.2d at 284-85; Sharon Steel Corp. v. EPA, 597 F.2d at 378; United States Steel Corp. v. EPA, 595 F.2d at 210, 213, 218.

44. See 43 Fed. Reg. 8962 (1978). See also United States Steel Corp. v. EPA, 649 F.2d 57475; Western Oil \& Gas Ass'n v. EPA, 633 F.2d at 805-06, 810; New Jersey v. EPA, 626 F.2d at 1041; Republic Steel Corp. v. Costle, 621 F.2d at 803; United States Steel Corp. v. EPA, 605 F.2d at 286; Sharon Steel Corp. v. EPA, 597 F.2d at 379; United States Steel Corp. v. EPA, 595 F.2d at 213-15.

45. When it published the final lists on March 3, 1978, the EPA invoked the "good cause" exception as follows:

The States are now preparing revisions to their State implenientation plans (SIPs) as required by sections 110 (a)(2)(I) and 172 of the Act. This enterprise, which must be completed by January 1, 1979, requires that the States have immediate guidance as to the attainment status of the areas designated under section 107(d). Congress has acknowledged this by imposing a tight schedule on the designation process and requiring the EPA to pronulgate the list within 180 days of the enactment of the amendinents. Under these circumstances it would be impracticable and contrary to the public interest to ig nore the statutory schedule and postpone publishing these regulations until notice and comment can be effectuated. For this good cause, the Administrator has nade these designations immediately effective.

43 Fed. Reg. 8962 (1978).

46. Republic Steel Corp. v. Costle, 621 F.2d 797, 803-05 (6th Cir. 1980).

47. United States Steel Corp. v. EPA, 605 F.2d 283, 286-90 (7th Cir. 1979), cert. denied, 444 U.S. 1035 (1980).

48. As the split in the circuits indicates, the question of what constitutes good cause under section 553 is a volatile issue. For discussion of this question, see authorities cited in note 17 supra.

49. Sharon Steel Corp. v. EPA, 597 F.2d 377, 380-81 (3rd Cir. 1979).

50. United States Steel Corp. v. EPA, 595 F.2d 207, 213 (5th Cir.), modjfied on rehearing, 598 F.2d 915 (1979).

51. New Jersey v. EPA, 626 F.2d 1038, $1043-45$ (D.C. Cir. 1980).

52. Id. at 1050; Sharon Stcel Corp. v. EPA, 597 F.2d at 381-82; United States Steel Corp. v. EPA, 595 F.2d at 218.

53. United States Steel Corp. v. EPA, 649 F.2d 572, 575-76 (8th Cir. 1981); Western Oil \& Gas Ass'n v. EPA, 633 F.2d 803, 810-12 (9th Cir. 1980). 
remanded the challenged designations for further proceedings.54 Rather than setting aside the challenged designations immediately, however, these courts left thein in effect pending the EPA's coinpliance on remand. ${ }^{55}$ The courts justified this novel reinedy by explaining that the decision was within their discretion "to shape an equitable reinedy," and that the equities weighed in favor of leaving the rules temporarily in effect. 56

United States Steel and Western Oil \& Gas are unprecedented. ${ }^{57}$ Other courts that sustain procedural challenges to informally proinulgated rules invalidate the rules pending the outcoine of the proceedings on remand regardless of the equities of the case, but United States Steel and Western Oil \& Gas suggest that courts nay use their equitable powers to protect challenged rules from immediate invalidation. Identification of the coinpeting considerations - the reasons both for and against immediate invalidation-is the first step in evaluating the propriety of this type of equitable relief following a successful procedural challenge to an informally promulgated rule.

\section{Reasons For and Against ImMediate InVAlidation of Improperly Promulgated Rules}

\section{A. Reasons for Leaving Challenged Rules in Effect Pending Procedures on Remand.}

A court fashioning a remedy for agency noncoinpliance witli section 553 has two primary reasons for leaving the challenged rule teinporarily in effect. First, and inost important, leaving a rule in effect may promote its statutory purpose. ${ }^{58}$ Second, it may be unreasonable

54. United States Steel Corp. v. EPA, 649 F.2d at 575-77; Western Oil \& Gas Ass'n v. EPA, 633 F.2d at $810-13$.

55. United States Steel Corp. v. EPA, 649 F.2d at 577; Western Oil \& Gas Ass'n v. EPA, 633 F.2d at 813 .

56. Western Oil \& Gas Ass'n v. EPA, 633 F.2d at 813; See also United States Steel Corp. v. EPA, 649 F.2d at 576.

57. It could be argued that these two cases are applications of a section of the CAA Amendments of 1977, 42 U.S.C. $§ 7607$ (d)(8) (Supp. III 1979), whicl provide:

[i]n reviewing alleged procedural errors, the court may invalidate the rule only if the errors were so serious and related to matters of such central relevance to the rule that there is a substantial likelihood that the rule would liave been significantly clianged if such errors had not been naade.

One could argue that the courts in United States Steel and Western Oil \& Gas, both CAA cases, were merely complying with this statute, and not einploying a novel equitable approacl. This argument, however, is flawed. Both courts specifically stated that their cloice of remedy was an exercise of equitable discretion; neither mentioned 42 U.S.C. $\$ 7607(d)(8)$ (Supp. III 1979). Nor did either court find that the procedural errors did the substantive damage contemplated by section $7607(d)(8)$.

58. See notes $60-61$ infra and accompanying text. 
to imvalidate the rule on merely procedural grounds. ${ }^{59}$ The force of these reasons may vary with both the type of rule cliallenged and the type of defect im agency procedure.

Federal agencies promulgate rules to further statutory purposes, ${ }^{60}$ and the result of an immediate invalidation of a challenged rule may be to frustrate the statutory purpose until a substitute rule is im place. Avoidimg this result is a major reason for leaving successfully challenged rules im effect pending agency action on remand. The strength of this argument, lowever, depends on the statutory purpose that the challenged rule was designed to implement. When the rule proinotes an urgent statutory purpose, the argument is compelling. ${ }^{61}$

Another argument for leaving the rule temporarily in effect is that it is unjust and unreasonable to allow a inere procedural "technicality"62 to upset an otherwise sound regulatory sclieme. Although intuitively appealing, this argument is not always persuasive. One of the functions of section 553 is to improve the substantive accuracy of rules by ensuring that the promulgatimg agency considers as inuch data and criticism as possible.63 When a rulemaking agency does not accept comment from interested parties, its rules are of questionable validity. Thus, a procedural challenge may imply a cliallenge to the substance of the rule as well. If the procedural defect does not relate to the notice and comment provisions of section 553, however, no substantive challenge should be implied. ${ }^{64}$ Thus, the propriety of leaving the rule in effect should vary according to the type of procedural defect.

59. See notes 62-64 infra and accoinpanying text.

60. "Congress often enacts regulatory legislation with broad substantive provisions: enactments, for example, making illegal 'unfair labor practices.' Congress then delegates to an agency the task of defining precisely the range of proscribed conduct." Mayton, The Legislative Resolution of the Rulemaking Versus Adjudication Problem in Agency Lawmaking, 1980 Duke L.J. 103, 104 (footnote omitted). See generally, K. Davis, ADMINistrative Law TrEaTISE, \$§ 3.01-.13 (1958); Shapiro, The Choice of Rulemaking or Adjudication in the Development of Administrative Policy, 78 HARV. L. REV. 921 (1965).

61. A strict statutory deadline inay be an indication that Congress considered the statutory purpose compelling. See, e.g., United States Steel Corp. v. EPA, 605 F.2d 283, 287-89 (5th Cir. 1979), cert. denied, 444 U.S. 1035 (1980) (statutory deadline sufficient indication of urgency of purpose such that "good cause" exception will apply).

62. See Umited States Steel Corp. v. EPA, 649 F.2d 572, 577 (8th Cir. 1981). See also, notes 118-21 infra and accompanyimg text. If the petitioner can offer no substantive criticism, the rule may be substantively sound. If the rule is sound, it presumably will not be changed after notice and comment on remand. Perhaps it is wasteful to remand the rule in such a case, only to have it reinstituted later in substantially the same form.

63. See notes 67-69 infra and acconpanying text.

64. The notice and comment provisions are the requirements of section 553 that have the most impact on the content of rules. See notes 67-69 infra and accompanying text. Presumably, if the agency violates section 553 inerely by not publishing a statement of basis and purpose or by making a rule effective immediately, the substance of the rule is not as likely to be questionable. 


\section{B. Reasons for Immediate Invalidation of Challenged Rules.}

There are several reasons for immediately invalidating a challenged rule following a finding of noncompliance with section 553 . First, because section 553 procedures serve to educate agencies and apprise them of the public interest the rule may be inaccurate and contrary to the public interest, and thus unworthy of being extended. Second, enforcement of a rule that results from improper procedure runs afoul of fundamental notions of democratic government. ${ }^{65}$ Third, leaving the rule temporarily in effect may have undesirable effects on the procedures on remand. ${ }^{66}$ Agam, the strength of these arguments varies with the rule being challenged and the type of procedural violation.

One function of the procedures of section 553 is to help agencies promulgate more rational, accurate rules by exposing the rulemaking process to criticism from interested commentators. ${ }^{67}$ According to the Senate Judiciary Committee report on the APA, "[agency] knowledge is rarely complete, and [the agency] must always learn the . . . viewpoints of those whom its regulations will affect. . . . [P]ublic participation .... in the rulemaking process is essential in order to permit administrative agencies to inform themselves." 68 If a rule is complex or far-reaching, the risk of imaccuracy increases. With a complex rule, it is imperative that the agency consider all available comment to ensure accuracy. ${ }^{69}$ Similarly, a rule of broad scope affects many individuals and therefore requires consideration of a wide variety of viewpoints to define the public interest. ${ }^{70}$ In our form of government, the public interest is defined by compromise between competing interests in soci-

65. See notes 75-81 infra and accompanying text.

66. See notes 82-86 infra and accompanying text.

67. NLRB v. Wyman-Gordon Co., 394 U.S. 759, 777-78 (1969) (Douglas, J., dissenting); National Tour Brokers Ass'n v. United States, 591 F.2d 896, 902 (D.C. Cir. 1978); LegisLATIve HisTORY, supra note 7, at 19-20, 200-01, 358-59. See also ATTORNEY GENERAL's COMM. ON ADministrative Procedure, final Report on Administrative Procedure in Government Agencies, S. Doc. No. 8, 77th Cong., 1st Sess. 101-02 (1941).

68. LeGisLative History, supra note 7, at 20.

69. See the cases cited at note 41 supra. In those cases, interested parties challenged the EPA's final designations. The designations were the result of an extensive and elaborate process of data accumulation. The public was not given an adequate opportunity to comment during this process, and inany of the designations were altered after publication. See text accompanying note 124 infra. The complexity of the designation scheme made public comment a necessity. Presunably, some of the later alterations of the designations would have been avoided had public comment been allowed See generally, Wright, The Courts and the Rulemaking Process: The Limits of Judicial Review, 59 CORNELl L. Rev. 375, 376 (notice and comment procedures needed when complex issues are involved).

70. A narrow, technical rule affects only a small segment of the population with limited interests. The agency's failure to listen to criticism is less important when the narrow "public" interest 
ety. ${ }^{71}$ By exposing proposed rules to criticisin froin interested parties, section 553 in principle helps agencies fashion rules more nearly in accordance with the public interest. ${ }^{72}$ When a court finds that a rule was promulgated in violation of section 553, failure to immediately invalidate it may subject parties to more than thirty days ${ }^{73}$ of regulation under a rule that is both inaccurate and contrary to the public interest.

The type of procedural defect has great bearing on the likelihood that a rule is maccurate or contrary to the public interest. The notice and comment provisions of section 553, more than the otler provisions, influence the degree to which rules are accurate and consonant with the

is readily ascertainable. See, e.g., American Frozen Food Inst. v. Train, 539 F.2d 107 (D.C. Cir. 1976).

71. Although commentators may disagree about the wisdom of this principle, they geuerally agree that it is one of the tenets of liberal democracy.

[A]lthough the "public interest" cannot be objectively defined, one can safely conclude that administrators who ignore relevant facts and who take the counsel of blind prejudice will serve the "public interest" only by the operation of cliance. Therefore, although a rulemaker's decisions cannot be "accurate" in the conventional sense, and although regulated parties lave no fundainental "right" to participate in rulemaking, the administrator owes a duty to the public to give serious consideration to all reasonable contentions and evidence pertinent to the rules he is considering.

Wright, supra note 69, at 380. See generally Barry, The Public Interest in THE Bias of PLuRALISM 159, 160 (W. Connolly ed. 1969); Connolly, The Challenge to Pluralist Theory in ThE Bias of Pluralism, supra, at 3; The Federalist No. 10 (A. Hamilton); Harmon, Administrative Policy Formulation and the Public Interest, 29 PuB. AD. Rev. 483, 485 (1969) ("the public interest is the continually changing outcome of political activity among individuals and groups within a democratic political system"); Reicl, The Law of the Planned Society, 75 YALE L.J. 1227, 1230-35 (1966); Note, Democratizing the Administrative Process: Toward Increased Responsiveness, 13 ARIz. L. REv. $835,838-40$ (1971).

72. Although the procedures of section 553 expose proposed rules to criticism, the efficacy of such criticism has been questioued:

Public participation in rulemaking procedures was a part, of course, of the original notice and comment procedures in the Administrative Procedure Act of 1946. It is fair to say, however, that while there is much public participation in such an informal written comment procedure, it is of a sort which gives only dubious satisfaction. A particular public comment sunply becomes one of a great mass of comments, and there is no overt reaction by the agency to each comment. Unless the individual commenting is filing views as part of an organization known to lave significant strength before the agency, the filing of a comment is much akin to dropping a feather into the Grand Canyon and trying to hear the impact.

Williams, Securing Fairness and Regularity in Administrative Proceedings, 29 AD. L. REv. 1, 16 (1977).

Concern that administrative agencies are not sufficiently democratic has resulted in a variety of suggestions for increasing input. See, e.g., Asimow, Public Participation in the Adoption of Interpretative Rules and Policy Statements, 75 Mich. L. REv. 520 (1977); Kocl, Public Procedures for the Promulgation of Interpretative Rules and General Statements of Policy, GEO. L.J. 1047 (1976). See also Comment, Inducement of Public Participation in Administrative Proceedings Through the Award of Attorneys' Fees, 30 BAYLOR L. REv. 785 (1978); Comment, The Need for an Additional Notice and Comment Period When Final Rules Differ Substantially from Interim Rules, 1981 DUKE L.J. 377.

73. In almost every case, compliance with section 553 on remand requires more than thirty days, the statutory minimum for promulgation of a new rule. See 5 U.S.C. $\$ 553$ (d) (1976). 
public interest. ${ }^{74}$ Hence, if a rule's only procedural flaw is the failure to print a statement of basis and purpose, concern for its substance slrould not compel invalidation.

The procedures of section 553 also serve to keep administrative agencies accountable and to legitimize agency action. Administrative agencies occupy a precarious position in a system of government that values limited power and the rule of law. ${ }^{75}$ It is a basic principle of deinocratic government that the consent of the governed is necessary to the legitimate exercise of power. Nonetheless, agencies often act as independent legislatures. ${ }^{76}$ To a certain extent, the procedures of section 553 legitimize this agency legislation. ${ }^{77}$ They ensure that interested parties are allowed to participate in rulemaking, in effect guaranteeing a modicuin of consent to agency action. ${ }^{78}$ Another fundamental of democratic government is that governmental power must be cliecked. Agencies have broad discretion when they inake rules under the mandate of vague statutes. ${ }^{79}$ To counter this discretion, section 553 renders agencies accountable by requiring thein to expose the ruleinaking process to public scrutiny and to articulate the basis and purpose of their rules. ${ }^{80}$

74. See note 64 supra and accompanying text.

75. See generally M. Vile, Constitutionalism and the Separation of Powers (1967); Freedman, Crisis and Legitimacy in Administrative Process, 27 STAN. L. Rev. 1041 (1975); Stewart, The Reformation of Administrative Law, 88 HARV. L. REv. 1669 (1975).

76. According to the traditional model of the administrative function, agencies were to be mere "transmission belts," carrying out the instructions of Congress. See Tarlock, Administrative Law: Procedural Due Process and Other Issues, 56 CHI.-Kent L. REv. 13 (1980); Stewart, supra note 75, at 1669-76. The administrative agencies have burgeoned however, into a "veritable fourth branch" with enormous impact on imdividuals, FTC v. Ruberoid Co., 343 U.S. 470, 487 (1952) (Jackson, J., dissenting), impact that is often not stamped with a congressional mandate. See Stewart, supra note 75, at 1676-88; LeGISLATIVE HistORY, supra note 7, at 383.

77. See generally Mayton, supra note 60, at 107.

78. See notes 67 \& 72 supra and accompanying text.

79. See Stewart, supra note 75 , at $1682-85$. The problem of keeping agencies accountable has become acute in recent years. Agencies, according to some commentators, have coine to abuse their discretion by, inter alia, serving the interests of narrow groups rather than those of the general public. See generally, G. McConnell, Private Power and American Democracy 33668 (1967); Freedman, supra note 75 at 1042.

80. Clearly, Congress intended section 553 to be a restraint on agency power. See LEGISLATIVE HistoRY, supra note 7, at 337-38, 349-51, 383-84, 392. In Shell Oil Co. v. FEA, the court stated: "[t]he agency's discretion, and thus its latitude for promulgating unwise rules, was to be restrained through this deliberately prescribed process for meaningful comment-a coinpetition of ideas, which replaced the restramt once performed by the marketplace's competition for profits." 574 F.2d 512, 516 (Temp. Emer. Ct. App. 1978). Some courts have gone so far as to equate the procedures of section 553 with due process of law. See, e.g., Fund for Animals v. Frizzell, 530 F.2d 982, 988 (D.C. Cir. 1975); Bell Lines, Inc. v. United States, 263 F.Supp. 40, 46 (S.D.W.Va. 1967). See generally Sinaiko, Due Process Rights of Participation in Administrative Rulemaking, 63 CAL. L. Rev. 886 (1975). 
Rules promulgated under improper procedures are therefore an affront to fundamental notions of democratic government. When a court allows such a rule to remain in force, it extends the life of an illegitimate exercise of power and possibly promotes abuses of agency power. This argument is especially compelling when the challenged rule is promulgated under a vague statute. When a vague statute is involved, the need is great to ensure that the agency remains accountable, and has not acted beyond its statutory mandate. ${ }^{81}$

This reason for immediately invalidating challenged rules will also vary in force as a function of the type of the procedural defect at issue in the case. Of the requirements in section 553, the notice and coinment provisions play the most important role in legitimizing agency actions and in keeping agencies accountable. Thus, when an agency fails to give notice and accept comment, this reason carries greater weight.

A third reason for immediately imvalidating challenged rules focuses on the effect that leaving them in place is likely to have on the procedures on remand. In a long line of cases, courts have held that allowing comment on rules after they have already become effective is not a satisfactory substitute for pre-promulgation comment. ${ }^{82}$ These courts reasoned that once a rule is effective, the agency responsible for the rule is unlikely to consider comments seriously. The agency becomes close-minded after making a final determination. ${ }^{83}$ Moreover, the agency's credibility is at stake; when the rule is in final form the

Proper section 553 procedures theoretically create a record that can be reviewed judicially, thereby increasing agency accountability. See, e.g., National Welfare Rights Org. v. Mathews, 533 F.2d 637, 648-49 (D.C. Cir. 1976). See also, Recent Developments, 44 FordHAM L. Rev. 402 (1975). But see Nathanson, Probing the Mind of the Administrator: Hearings, Variations and Standards of Judicial Review Under the Administrative Procedure Act and Other Federal Statutes, 75. Colum. L. Rev. 721, 754, 754-56 (1975).

81. See Stewart, supra note 75. Professor Stewart argucs as follows:

Vague, general, or ambiguous statutes create discretion and threaten the legitimacy of agency action under the "transmission belt" thcory of administrative law. Insofar as statutes do not effectively dictate agency actions, individual autonomy is vulnerable to the imposition of sanctions at the unruled will of executive officials, major questions of social and economic policy are determined by officials who are not formally accountable to the electorate, and both the checking and validating functions of the traditional model are impaired. However, rather than being the exception, federal legislation establishing agency cliarters lias, over the past several decades, often been strikingly broad and nonspecific, and lias accordingly generated the very conditions which the traditional model was designed to eliminate.

Id. at 1676-77 (footnotes omitted).

82. See, e.g., Slraron Steel Corp. v. EPA, 597 F.2d 377, 381 (3d Cir. 1979); National Tour Brokers Ass'n v. United States, 591 F.2d 896, 899 (D.C. Cir. 1978); Wagner Elec. Corp. v. Volpe, 466 F.2d 1013, 1019 (3rd Cir. 1972); City of New York v. Diamond, 379 F. Supp. 503, 517 (S.D.N.Y. 1974).

83. See cases cited at note 82 supra. 
agency may take a defensive posture. ${ }^{84}$ This argument also seems to apply when the rule is not fully effective but only in place temporarily. Substantial rule revision taxes the agency; a change in the rule requires altering the machinery of impleinentation, enforcement, and documentation. ${ }^{85}$ The agency has good reason to be close-minded once the rule is remanded. As a result, it is likely that if the rule is not invalidated immediately the procedures on remand may be a mockery of section 553 , with the agency giving little serious consideration to the criticisms and comments of the interested parties. ${ }^{86}$ Consequently, the perinanent rules that result from the remand procedures are likely to be the temporary rules in a shightly revised forn. This is unacceptable because the temporary rules must be subjected to criticism. As discussed previously, improperly promulgated rules are possibly inaccurate, ${ }^{87}$ possibly contrary to the public interest, 88 and definitely an affront to notions of proper government. 89

Both the type of rule and the type of procedural defect in question affect the force of this argument for invalidation. If, for example, the rule has caused the agency to erect elaborate enforcenent inechanisms, the agency has mcreased motive for disregarding criticism..$^{90}$ Depend-

84. See National Tour Brokers Ass'n v. United States, 591 F.2d 896, 902 (D.C. Cir. 1978). The National Tour Brokers court presented another reason for rejecting post-promulgation comment:

[A]n individual . . . should have an opportunity to address a proposal before, not after, a decision on whether it should be impleinented has been inade. The fact that the inatter has been prejudged might very well discourage disclosure of pertinent points of view.

For example, someone might be inclined to respond to an initial proposal because this could be done without the aid of professional advice. But he or she might not be similarly inclined to file a petition responding to the proposal's adoption because of a belief that to do so would require such advice.

Id. at 902 n.24 (quoting Entry Control of Brokers, 126 M.C.C. 476, 531 (1977)). In Sharon Steel Corp. v. EPA, the court offered yet another reason: "If a period for comments after the issuance of a rule could cure a violation of the APA's requireinents, an agency could negate at will the Congressional decision that notice and an opportunity for comment nust precede proinulgation." 597 F.2d 377, 381 (3d Cir. 1979).

85. Presumably, a change in the teinporary rule would require the agency to publish notice of the change, and to educate agency personnel and regulated meinbers of the public regarding the change.

86. Of course, if an agency were intent on laving a challenged rule in effect in the future, it would not matter whether the rule was invalidated immediately or left in place during compliance with section 553. In either situation the agency would disregard comments.

87. See notes 67-69 supra and accompanying text.

88. See notes $70-72$ supra and accoinpanying text.

89. See notes 75-80 supra and accompanymg text.

90. See, e.g., Maryland v. EPA, 530 F.2d 215 (4th Cir. 1975), vacated and remanded, 431 U.S. 99 (1977). Maryland involved a challenge to several regulations that were part of a coinplex plan devised by the State of Maryland and the EPA for achieving air-quality standards im metropolitan Baltimore. See id. at 217-19. One of the regulations at issue was the Employer's Provision for Mass Transit Priority Incentives (EMTI). The EMTI plan was devised by the EPA and required each employer of more than 700 einployees within the region to submit to the EPA a plan for 
ing on the procedural defect, however, this argument may be less persuasive. If there has been proper notice and comment, the agency's determination to adhere to its rule may be justifiable. In some situations, therefore, the two relevant concerns-the type of rule and the type of procedural defect-may offset each other.

\section{The Propriety of Balancing the Competing Considerations.}

As the foregoimg illustrates, competing considerations confront a court faced with the decision whether to leave informally promulgated rules temporarily im effect following a successful procedural challenge. The question remams, however, whether it is appropriate for courts making this decision to use their equitable power ${ }^{91}$ to balance these considerations. ${ }^{92}$ On the one hand, section 706 of the APA $^{93}$ appears to preclude courts from using an equitable approach because it appears to compel immediate invalidation of all rules found to have been improperly proinulgated. It reads in pertinent part: "The reviewing court

encouraging employees to use mass transportation rather than automobiles. The plan went into effect on December 12, 1973, without having been mentioned in any previous Maryland or EPA proposal. Thus, neither the State of Maryland nor the general public was afforded an opportunity to comment on the plan before it went into effect. The EPA did, however, offer to accept postpromulgation comments. Id. at 221 .

The Court of Appeals for the Fourth Circuit held the EMTI plan invalid "as a result of the lack of notice ... and failure to comply with the notice and publication requirements of the Administrative Procedure Act, 5 U.S.C. $\$ 553(\mathrm{~b})(3)$." Id. at 222. The court explained that "[t]he reception of comments after all the crucial decisions have been made is not the same as permitting active and well prepared criticism to become a part of the decision-making process." Id.

In Maryland, the controlling consideration in the remedy decision was the effect of that decision on the procedures on remand. Considering the complexity of the statutory scheme involved, see id. at 218-19, the agency would have been tempted to ignore postpromulgation comment in order not to disrupt the overall plan and lose face. See note 85 supra and text accompanying notes 83-85 supra. Notably, the regulations cliallenged in this case are still in effect. See 40 C.F.R. $\S 52.1105$ (1981).

91. It is well established that a court considering a petition for review of an agency action "may adjust its rehef to the exigencies of the case in accordance with the equitable principles governing judicial action." Ford Motor Co. v. NLRB, 305 U.S. 364, 373 (1939). Accord, Sharon Steel Corp. v. EPA, 597 F.2d 377, 381 (3d Cir. 1979); Indiana and Michigan Electric Co. v. Federal Power Comm'n, 502 F.2d 336, 346 (D.C. Cir. 1974), cert. denied, 420 U.S. 946 (1975).

Although Ford Motor $C o$. has jeen read to hold that the power to fashion equitable remedies in these cases is vested in the courts of appeals, see $\mathrm{K}$. DAvis, ADMINISTRATIVE LAw TEXT 441 (3d ed. 1972), it is not clear whether a district court could also use the balancing approach suggested here. As a practical matter, however, it is of no great import that the district courts may not have this power. The overwhelming majority of actions for review of agency rules are brought in the appellate courts. See W. Gellhorn, C. BYSE \& P. STrauss, supra note 21, at 917-19.

92. Manifestly, equity would require the court making this decision to balance the competing considerations. As Justice Frankfurter phrased it: "It is always the duty of a court of equity to strike a proper balance between the needs of the plaintiff and the consequences of giving the desired relief." Eccles v. Peoples Bank, 333 U.S. 426, 431 (1948).

93. 5 U.S.C. $\$ 706$ (1976). 
shall . . . (2) hold unlawful and set aside agency action, findings, and conclusions found to be . . . (D) without observance of procedure required by law."94 On the other hand, the courts in United States Steel Corp..$^{95}$ and Western Oil \& Gas $^{96}$ used their equitable discretion unhesitatingly and left the designations temporarily in effect pending agency action on reinand.

The approach taken by the United States Steel and Western Oil \& Gas courts is preferable. First, section 706 probably does not apply to the specific question of whether courts can leave rules in effect during the procedures on remand. ${ }^{97}$ Along with the above-quoted language, section 706 contains a provision that requires reviewing courts to take "due account . . . of the rule of prejudicial error." 98 According to the Senate Judiciary Committee's Report on the APA, this provision "means that a procedural omission which has been cured by affording the party the procedure to which he was originally entitled is not a reversible error."99 Although the Report speaks in terns of omissions that have been cured, it seems equally applicable to omissions that will be cured. Accordingly, because successful challengers to inforinally promulgated rules are guaranteed proper procedures on remand, ${ }^{100}$ the procedural omissions found by the courts in these cases probably do not constitute reversible error. Thus, section 706 very likely does not compel courts to invalidate rules immediately.

A second reason for rejecting the notion that section 706 precludes courts from leaving challenged rules temporarily in effect hinges on the function of the quoted portion of section 706. Section 706(2)(D) is an enforcement provision for the APA; its essential function is to promote the purposes of the procedural requirements of the APA. With regard to section 553, this portion of section 706 is designed to ensure that rulemaking is informed ${ }^{101}$ and legitimate. ${ }^{102}$ Hence, there is little purpose to be served by applying this provision in cases in whicll the rulemaking process has been substantially informed and legitimate. In such cases the reasons for leaving the rules temporarily in effect out-

94. Id.

95. 649 F.2d 572, 577 (8th Cir. 1981).

96. 633 F.2d 803, 813 (9th Cir. 1980).

97. This would explain why courts invalidating successfully challenged rules so seldom refer to section 706. See generally note 23 supra and accompanying text.

98. 5 U.S.C. $\$ 706$ (1976).

99. LEGISLATIVE HISTORY, supra note 7, at 214.

100. The quality of the procedures on remand, however, will not always be satisfactory to the challenging party. See notes 82-90 supra and accompanying text, and notes 131-34 infra and accompanying text.

101. See notes 67-72 supra and accompanying text.

102. See notes 75-80 supra and accompanying text. 
weigh the reasons for invalidating thein immediately. ${ }^{103}$ When the competing considerations weigh leavily in favor of leaving the rules in effect, immediately invalidating challenged rules will not promote the purposes of section 553 to any appreciable extent. Enforcing section 706(2)(D) in sucl cases is likely to liave undesirable effects. Thus, because the purpose of section 706 should not require immediate invalidation in every instance, section 706 slould not bar courts from using an equitable approach.

\section{Evaluation of UNITED STATES STEEL AND WESTERN OIL \& GAS}

The United States Steel and Western Oil \& Gas courts departed from precedent by choosing the equitable remedy of leaving the challenged designations in effect. ${ }^{104}$ In support of this novel remedy clioice, the Western Oil \& Gas court explained that it did not want to interfere with "the operation of the Clean Air Act in the State of California."105 The United States Steel court followed this reasoning ${ }^{106}$ and offered a second reason for not immediately invalidating the cliallenged designations. ${ }^{107}$ Noting that United States Steel liad not challenged the merits of the designations, the court wrote that it was "appropriate" to leave the designations in effect because "United States Steel liad elected to rest its challenge . . p primarily on procedural grounds." 108

The United States Steel and Western Oil \& Gas courts touched on two previously described reasons for leaving rules in effect-promotion of statutory purpose and the inequity of invalidating for procedural reasons alone. They did not, lowever, adequately discuss several other considerations that should liave influenced tle remedy decision. Moreover, their reliance on statutory purpose and equitable considerations may have been unjustified. ${ }^{109}$

103. In other words, the reasons for leaving the rules in effect, see text accompanying notes 5864 supra, would carry some weight, but the first two reasons for invalidating, see text accompanying notes 67-81 supra, would already have been satisfied.

104. See note 56 supra and accompanying text.

105. 633 F.2d 803, 813 (9th Cir. 1980).

106. 649 F.2d 572, 576-77 (8th Cir. 1981).

107. Id. at 577 .

108. Id.

109. See notes 112-17 infra and accoinpanying text. 
A. Competing Considerations Facing the United States Steel and Western Oil \& Gas Courts: Reasons for Leaving the Designations in Effect.

The courts' desire to proniote statutory purposes weighed heavily in the remedy decision in both United States Steel and Western Oil \& Gas $^{110}$ This emphasis on statutory purposes was justified in principle; Congress made clear in the 1977 Amendments to the Clean Air Act (CAA) that it considered clean air to be of crucial importance. ${ }^{111}$ However, invalidating the cliallenged designations would not necessarily have frustrated the purposes of the Amendments. ${ }^{112}$ The final goal of the Amendments was the attainment of certain air-quality standards. ${ }^{13}$ The states were to use the designations as the basis for formulating state-wide plans by 1979 to implentent, maintam, and enforce the standards. ${ }^{14}$ The designations also triggered an offset policy, in effect limiting pollution from new or modified sources in nonattainment areas. ${ }^{115}$

Thus, if the challenged designations had been invalidated, the goals of the CAA Amendments might have been hindered because first, the states would temporarily have had inconplete infornation with which to formulate their implementation plans, and second, the pollu-

110. See text accompanying notes 105-07 supra.

111. The strict statutory deadlines set up by the Amendments show that it was Congress's desire to achieve clean air as expeditiously as possible. See 42 U.S.C. \$ 7407 (Supp. III 1979). See generally Republic Stcel Corp. v. Costle, 621 F.2d 797, 804 (6th Cir. 1980); United States Steel Corp. v. EPA, 605 F.2d 283, 287-88 (7th Cir. 1979).

112. See generally Comment, Ageney Discretion to Accept Comment in Informal Rulemaking: What Constitutes "Good Cause" under the Administrative Procedure Act?, 1980 B.Y.U. L. REv. 93, 111-12.

Other courts that considered the challenges to the EPA's list of designations, see note 41 supra, gave conflicting accounts of the effect immediate invalidation would have had on the functioning of the CAA. For example, coinpare the following statements:

We note that if we were to remand in this case, the entire deadline scheme would be thrown into complete disarray. State Implementation Plans, which were scheduled to be (and presumably were) formulated by January 1 , would have to be further delayed while the EPA proceeded with yet another notice and comment period, and after promulgation of those designations states would have to repeat the hearing-consultation process in order to resubmit implementation plans . . . [R]emand in this case would permit U.S. Steel to continue the very procrastination which Congress sought to end.

United States Steel Corp. v. EPA, 605 F.2d 287, 288 n.5 (7th Cir. 1979);

[T] he respective states already liad most of the information contained in the EPA's designations, simce those designations were based on submissions by the states. The statute indicates that the EPA's role is limited to reviewing the state designations and modifying them where necessary .... The states could have begun the revisions [of their implementation plans] with the information on hand, changing them later as required by EPA alterations of the $\$ \S 7407$ (d) list.

United States Steel Corp. v. EPA, 595 F.2d 207, 214 (5th Cir.), modified on rehearing, 598 F.2d 915 (5th Cir. 1979).

113. 42 U.S.C. $\S \S 7410,7502$ (Supp. III 1979).

114. $I d$.

115. Id. $\S 7503$ See note 34 supra. 
tion level might have increased in nonattainment areas because the offset restrictions would not have applied. It was not shown, however, in either United States Steel or Western Oil \& Gas that invalidation for the amount of time required for compliance with section 553 would have put statutory deadlines out of reach.116 Nor was there any evidence that the pollution levels would have increased greatly as a result of the lack of offset restrictions in the areas in question. ${ }^{117}$

The United States Steel court reasoned that it is inappropriate to invalidate a rule on primarily procedural grounds. ${ }^{118}$ Considering the facts of the case, the court was justified in its analysis. United States Steel's challenge was primarily procedural. ${ }^{119}$ "[O]f the three mining companies . . . who challenged the EPA's mitial nonattainment designations, only U.S. Steel did not submit detailed inforination to support its claim that the designations should be modified." 120 Because United States Steel waived its opportunity to object to the substance of the designations, its procedural challenge arguably did not call the substance of the designations into question. ${ }^{121}$

\section{B. Competing Considerations Facing the United States Steel and Western Oil \& Gas Courts: Reasons for Invalidating the Designations Immediately.}

A successfully challenged rule may be both inaccurate and contrary to the public interest. ${ }^{122}$ This consideration should have influenced the United States Steel and Western Oil \& Gas decisions. There was a substantial risk that the designations challenged in both cases were inaccurate. The designations challenged in United States Steel

116. In United States Steel the ehallenged designations related to an area comprising only 25 square miles. $649 \mathrm{~F} .2 \mathrm{~d}$ at $573 \mathrm{n} .2$. Hence, Minnesota would probably not have been substantially hindered in formulating an implementation plan. See also United States Steel Corp. v. EPA, 595 F.2d 207, 214 (5th Cir.), modified on rehearing 598 F.2d 915 (5th Cir. 1979).

117. The cases do not indicate what effect removing the offset restrictions would have had on the areas in question. One can speculate that United States Steel or Western Oil and Gas might have constructed or modified their facilities to the detriment of air quality.

118. 649 F.2d at 577 . The court did not explicitly state why the "primarily" procedural challenge did not merit invalidation of the designations. It is a fair inference, however, that the court thought it would be inequitable to invalidate on the basis of a procedural ehallenge alone, since United States Steel could challenge the merit of the nonattainment designations in further administrative hearings.

119. Id.

120. $\mathrm{Id}$.

121. See note 64 supra and accompanying text. The Western Oil \& Gas court failed to address this reason for leaving the designations in effect. The opinion does not reveal whether Western Oil and Gas had the same opportunity to comınent that United States Steel had.

122. See notes 67-73 supra and accompanying text. 
related to the Mesabi Iron Range area of Minnesota. ${ }^{123}$ Six months after United States Steel commenced its action agamst the EPA, a new study of the air quality im the area was commissioned, ${ }^{124}$ which imphes that the original designations were inaccurate. According to the Court of Appeals for the Ninth Circuit, the designations challenged in Western Oil \& Gas were "hastily drafted."125 The court was not satisfied with the designations "on substantive grounds." 126

The United States Steel and Western Oil \& Gas courts were apparently not concerned that by leaving the designations im effect they were extending the life of an illegitimate agency action. The EPA avoided all of the section 553 procedurcs in the pronulgation of the designations, ${ }^{127}$ thereby violating the principles of legitimization and accountability. ${ }^{128}$ This reason for invalidation should have been considered in the two decisions. Because the CAA Amendments of 1977 were quite explicit, however, the EPA had a clear congressional mandate to promulgate the designations. ${ }^{129}$ The need for EPA accountability was therefore not as great as it would have been had the statute been vague. Similarly, the designation presumably did not adversely affect vital interests of either United States Steel or Western Oil and Gas. As a result, the need for legitimization was not as great as it could liave been. ${ }^{130}$ It should therefore have been a comparatively minor factor in the United States Steel and Western Oil \& Gas decisions.

The United States Steel court, but not the Western Oil \& Gas court, indirectly dealt with the negative effect that leaving the designations in place would have on the procedures on remand. United States Steel argued that the EPA and the Minnesota Pollution Control Agency would "feel no compulsion to act expeditiously on remand" 131 unless

123. $649 \mathrm{~F} .2 \mathrm{~d}$ at 573.

124. Id. at 573 n.3.

125. 633 F.2d at 806 .

126. $I d$.

127. See text accompanying notes $42-45$ supra.

128. See generally notes 75-80 supra and accompanying text.

129. The Amendments specifically instructed the EPA to promulgate the final lists. 42 U.S.C. $\$ 7407$ (Supp. III 1979). Hence, in promulgating the lists the EPA was not legislating on its own but merely carrying out a congressional directive. The decisions would have been inore questionable if Congress had delegated to the EPA the power to protect the environment and the EPA had contrived the designation scheme itself.

130. United States Steel and Western Oil \& Gas do not discuss in detail what harm or expense the two companies would have suffered if the offset policy were in effect. Presnmably, the larm could not have been great. The offset policy was not an absolute bar to construction or inodification. The only restriction was that the building or modification could not increase pollutant levels. See note 34 supra. But see United States Steel Corp. v. EPA, 595 F.2d 207, 211 (5th Cir. 1979) ("the designations have consequences . . . that constitute a snbstantial injury to the petitioners").

131. 649 F.2d at 577 . 
the designations were invalidated. In response, the court directed the two agencies "to promptly hear and resolve the existing controversy and to consider United States Steel's comments witliout regard to the nonattainment designations that we have permitted to remain in effect." 132 The court was, of course, correct to give such directions. The EPA had notive to disregard United States Steel's comments because changing the teniporary designations required a substantial effort. ${ }^{133}$ Furthermore, because there had been no previous notice and comment, the need was great for full section 553 procedures on remand. ${ }^{134}$ By instructing the agency to consider United States Steel's comments fully ${ }^{135}$ the court at least attempted to minimize the chance that the teinporary designations would go untested. Since there was a substantial risk that the designations were inaccurate, ${ }^{136}$ and smce there had been no previous criticism, ${ }^{137}$ it was important that the designations be subjected to criticism.

\section{CONCLUSION}

After sustaining a procedural challenge to a rule proinulgated by a federal administrative agency, courts nuust fashion a remedy. The conflictimg considerations involved in fashioning this reinedy require a balancing approach. The courts should follow the lead of the eighth and ninth circuits in United States Steel and Western Oil \& Gas and adopt such an approach.

The courts should recognize, lowever, that the United States Steel and Western Oil \& Gas courts failed to properly apply this balancing approach. They neither articulated nor considered all of the reasons for or agamst invalidating. Moreover, they attached inordinate weight to promotimg the Clean Air Act Amendments of 1977. Nevertheless, the basic approach of both courts was correct, and there is no indication that such an approach will not work well in the future. As courts become more accustomed to evaluating the coinpeting concerns in these cases, they are likely to become more adept at applying a balancmg approach.

David B. Chaffin

\footnotetext{
132. Id.

133. See generally text accompanying notes 83-85 supra.

134. See notes 82-86 supra and accompanying text.

135. $649 \mathrm{~F} .2 \mathrm{~d}$ at 577 .

136. See text accompanying notes 124-26 supra.

137. See 649 F.2d at 574. Consequently, the need to have the designations tested was greater than it would have been had the procedural problem been minor.
} 